\title{
PTEN Gene Mutation
}

National Cancer Institute

\section{Source}

National Cancer Institute. PTEN Gene Mutation. NCI Thesaurus. Code C121369.

A molecular genetic abnormality indicating the presence of a mutation in the PTEN gene on chromosome 10q23.3. 